\title{
Effectiveness of mindfulness-based cognitive therapy on mothers' psychological well-being of children with Autism and reduction of symptoms these children
}

\author{
Sara Aghababaei ${ }^{1}$, Maryam Taghavi ${ }^{2}$ \\ 1-Assistant Professor, Department of Psychology, Shahid Ashrafi Esfahani University, Esfahan, Iran \\ (Corresponding Author). E-mail: sara.aghababaei@ymail.com \\ 2- M.A in Personality Psychology, Khomeinishahr Branch, Islamic Azad University, Esfahan, Iran.
}

Received: 08/10/2019 Accepted: 06/01/2020

\begin{abstract}
Introduction: The birth of a child with autism has a huge impact on the psychological wellbeing of parents, especially mothers.

Aim: The aim of this research was to investigate effectiveness of Mindfulness-Based Cognitive Therapy on the mothers' psychological well-being of children with autism and reduction of symptoms these children.

Method: The research method was quasi-experimental with a pre and post design with control group. The Statistical population consisted of all mothers of children with autism who referred to autistic centers in Isfahan city. In order to do the research, 30 mothers of autistic children were selected by available sampling method. They were randomly divided into two groups: control and experimental (15 in the control group and 15 in the experimental group). The experimental group received 10 sessions of Mindfulness-Based Cognitive Therapy. The instruments used in this research were the Psychological Well-being Scale of Ryff and Gilliam Autism Rating Scale (GARS).
\end{abstract}

Results: The results of covariance analysis (by used spss-22) indicated that Mindfulness-Based Cognitive Therapy had a significant effect on the psychological well-being of mothers. Also, the results showed that this training had a significant effect on the symptoms of autistic children in the areas of stereotypical behaviors, interactions and social communication $(\mathrm{p}<0.01)$.

Conclusion: According to the results, this method can be used to help parents' mental health and improving symptoms of autism children.

Keywords: Mindfulness-based cognitive therapy, Psychological well-being, Symptoms of autism

\footnotetext{
How to cite this article : Aghababaei S, Taghavi M. Effectiveness of mindfulness-based cognitive therapy on mothers' psychological well-being of children with Autism and reduction of symptoms these children. Shenakht Journal of Psychology and Psychiatry. 2020; 6 (6): 88-100 .URL: http://shenakht.muk.ac.ir/article-1-637-fa.pdf
}

Copyright ( 92018 the Author (s). Published by Kurdistan University of Medical Sciences. This is an open access article distributed under the terms of the Creative Commons Attribution-Non Commercial License 4.0 (CCBY-NC), where it is permissible to download, share, remix, transform, and buildup the work provided it is properly cited. The work cannot be used commercially without permission from the journal. 


\title{
اثربخشى آموزش شناخت درماذى مبتنى بر ذهن آكاهى بر بهزيستى روان شناختى مادران كودكان اوتيسم و علأمم كودكان
}

\author{
سارا آقابابايى'، مريم تقوى'

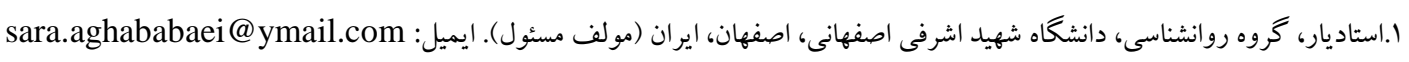

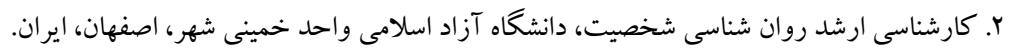

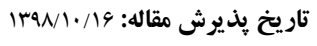

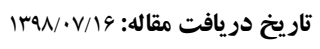

جكيده مقدمه: تولد كود كك اوتيسم ضربههاى زيادى را بر بهزيستى روان شناختى والدين، به ويزه مادران وارد مى كند. هدف: يزوهش حاضر با هدف بررسى اثر بخشى آموزش شناخت درمانى مبتنى بر ذهن آكاهى بر بهزيستى روانشناختى مادران

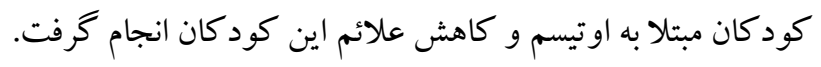

روش: روش ئزوهشى شبه آزمايشى با طرح بيش آزمون-ِّ آزمون با گروه كنترل بود. جامعهآمارى يثزوهش، شامل كليه مادران كود كان مبتلا به اوتيسم است كه به مراكز اوتيسم شهر اصفهان مراجعه كرده بودند. به منظور انجام آزمايش، ·ب نفر از مادران كود كان

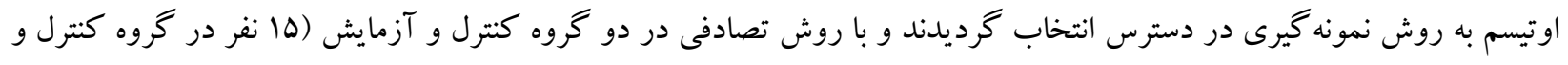

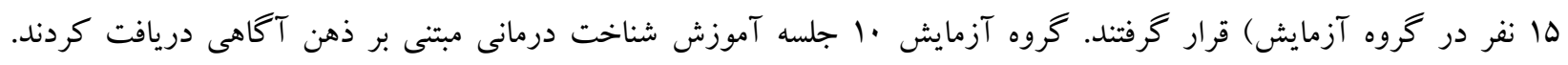
ابزارهاى مورد استفاده در اين بثزوهش مقياس بهزيستى روان شناختى ريف و مقياس درجه بندى اوتيسم گيليام (كارز) بود. يافتهها: نتايج تحليل كواريانس (با استفاده از spss-22) نشان داد كه آموزش شناخت درمانى مبتنى بر ذهن آكاهى داراى تأثير

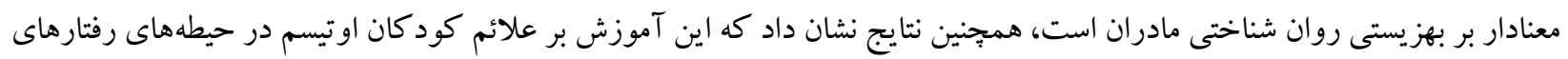

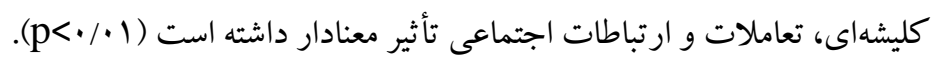
نتيجه كيرى: با توجه به نتايج حاصله مى توان از اين شيوه براى كمكك به سلامت روانى والدين و بهبود علائم كودكان اوتيسم استفاده

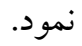
كليد وازهها: شناخت درمانى مبتى بر ذهن آكاهى، بهزيستى روانشناختى، علائم اوتيسم 
افسردگى، استرس و حتى طلاق والدين مىشود (هارتلى

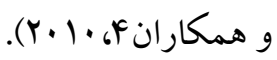

به طور كلى، تربيت كودكك براى والدين جالش هايى را به دنبال دارد كه مى تواند منجر به ايجاد استرس در آنها شود. اين در حالى است كه والدين كودكان اوتيسم نسبت به والدين كود كان عادى استرس بيشترى را تحمل

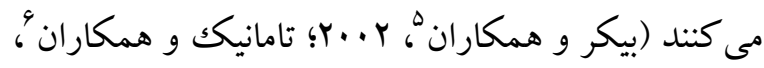

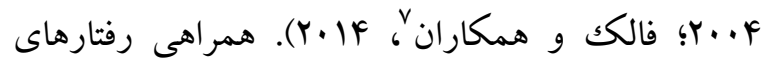
نامناسب با اوتيسم مىتواند ميزان استرس والدين را افزايش دهد. والدين اين كودكان گزارش مىدهند كه مشكلات در تعاملات اجتماعى، رفتارهاى كليشهاى و احساس ناتوانى والدين در كنترل رفتارهاى نامناسب كودكك مى تواند شدت استرس را در آنها بيشتر كند

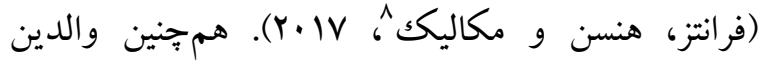

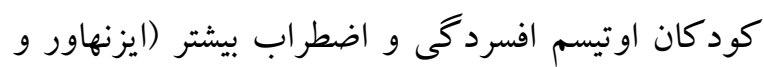

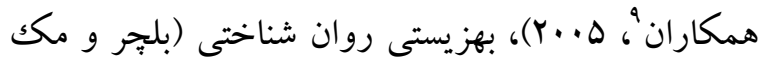

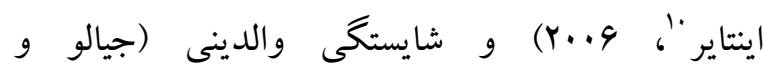

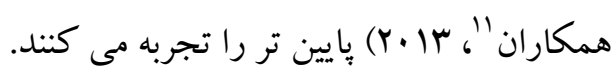
در اين ميان، مادران فشار روانى بيشترى را نسبت به يدران خواهند داشت. اكثر مادران به هنگًام تشخيص اختلال

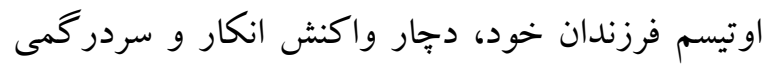
شده و طيف كسترده ای از هيجانات از قبيل خشم، غمخينى، گريه و سو گك را نشان مىدهند (افشارى و و همكاران، هیr|). در اين ميان نقش اصلى جلو خيرى از جنين شرايطى، افزايش بهزيستى روانشناختى مادران اين

\footnotetext{
4- Hartly\&etal

5 - Baker et al

${ }^{6}$ - Tomanik et al

7. Falk et al

${ }^{8}$ - Frantz, Hansen \& Machalice

9 - Eisenhower et al

${ }^{10}$ - Blacher \& McIntyre

11 - Giallo
}

\section{مقدمه}

اختلال طيف اوتيسم ' اختلالى عصبى - رشدى است كه بهعنوان شايع ترين اختلال رشدى در حال بيشرفت شناخته

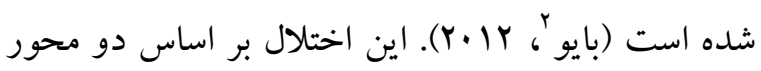
رفتارى؛ تأخير يا نقص در ارتباط - تعامل اجتماعى و رفتارهاى تكرارى و علايق محدود تشخيص داده مىشود

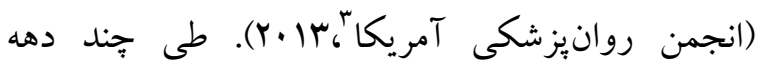
كذشته ميزان شيوع اختلال طيف اوتيسم افزايش يافته به كونه ای كه امروزه در هر 91 كودك،، ا كودكك در سن

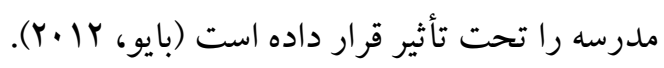

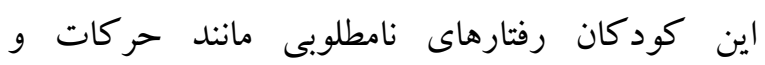
رفتارهاى كليشهاى، برخاشخرى و رفتارهاى خودآزارى از خود نشان مىدهند. آنها همجينين در فهم و استفاده از قوانين و رفتارهاى اجتماعى، اشارهاى، محاورهاى، رفتارهاى غير كلامى و هماهنگ حركى حتى دجار مشكل

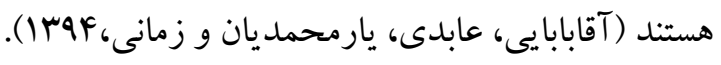

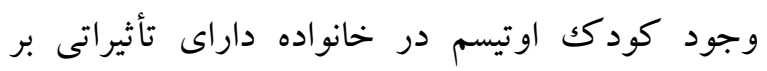
سازش يافتخى زناشويى، روابط خواهران و برادران و فعاليتهاى روزمره خانواده است. افزون بر اين موارد، اين اختلال فقر مالى زيادى را بر خانواده تحميل مى كند. والدين كود كان اوتيسم، انزواى اجتماعى و اختلاف هاى زناشويى را تجربه مى كنند. خواهران و برداران آنها داراى انواع مشكلات سازش يافتخى و روابط آسيبديده هستند. از آنجايى كه اوتيسم نيازمند مصرف منابع انسانى و مالى خانواده براى كودك است و ازآنجايى كه اين خواستهها، با مراقبت از كودكك مرتبط هستند، والدين وقت و فرصت كافى براى خود ندارند كه اين منجر به

\footnotetext{
1- Autism Spectrum Disorder

- Baio

${ }^{3}$ - American Psychiatric Association
} 
آكاهى فراشناختى، تمر كززدايى و ايجاد بذيرش نسبت به

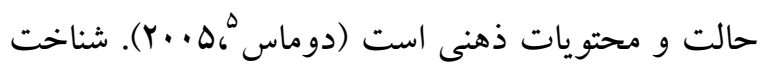
درمانى مبتنى بر ذهن آكاهى شامل مديتيشن هاى مختلف، يو گاى كشيدگى، آموزش مقدماتى درباره افسردگى و جند تمرين شناخت درمانى است كه ارتباط بين خلق، افكار و احساس را نشان مى دهد. تمام اين تمرين ها، به نوعى توجه به موقعيتهاى بدنى و بيرامونى را در لحظه حال ميسر مىسازد و بردازش هاى خود كار افسردگى را كاهش مىدهد (تيزدل، سگال و ويليامز ؛

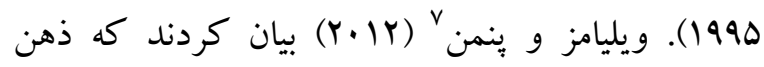
آكاهى فنى براى بررسى محر ككهاى زيربنايى شناخت ها

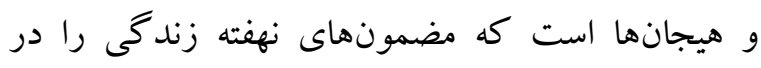
معرض آكاهى قرار مىدهد؛ به اين ترتيب بدون قضاوت يا سرزنش نشان مىدهد كه اولاً هيجانات مركب از افكار، حسهاى بدنى، احساسات خام و تكانه هستند، آنها اطلاعات درونى و بيرونى را ادغام مى كنند و علائمى هستند كه فقط بايد در اين لحظه بدون قضاوت و يا سرزنش مشاهده شده و مورد توجه قرار بحيرند.

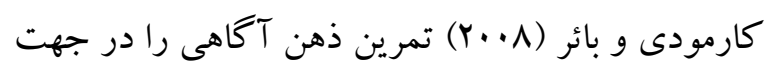
كاهش استرس، اضطراب و افزايش بهزيستى روانشناختى مؤثر مىدانند (احمدوند، حيدرى نسب و

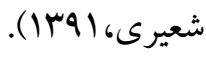
كاجيا و همكاران^ (Y. (Y) تأثير مداخلات مبتنى بر ذهن آكاهى را بر استرس و بهزيستى روان شناختى در مادران كودكان اوتيسم مورد مطالعه قرار دادند. آنها به اين نتيجه دست يافتند كه مداخله ذكر شده مى تواند بهزيستى
كود كان مى باشد كه به عنوان بايه هاى اصلى خانو اده در نظر كرفته مىشوند. منطقى به نظر مىرسد كه مؤلفههاى درمانى مناسب براى كاهش تعاملهاى نامناسب والد-

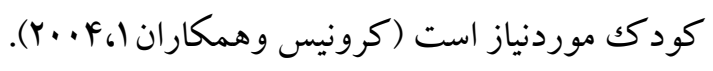
بهزيستى روان شناختى پايين و استرس بالا در مادران كودكان اوتيسم از جهت بالينى اهميت زيادى دارد، به اين ترتيب كه مىتواند درمان و روند آن رادر كود كان

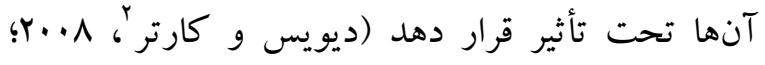

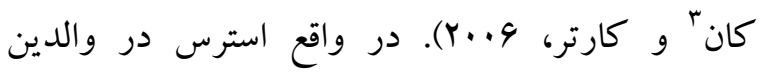
مىتواند بهزيستى روان شناختى كودكان را تحت تأثير قرار داده و تأثير مداخلات را كاهش دهد (اوسبورن و

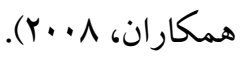
بهزيستى روانشناختى شامل دريافت هاى فرد از ميزان هماهنكى بين اهداف معين و ترسيم شده با بيامدهاى عملكردى است كه در فرآيندهاى ارزيابى مستمر به دست مى آيد و به رضايت درونى و نسبتاً يايدار در توالى إلى الى زندكى منجر مىشود (مؤمنى و كريمى، سوسا ). آموزشهايى به منظور افزايش بهزيستى روان شناختى والدين و كاهش استرس آنها مى تواند بر سلامت روانى والدين كودكان اوتيسم تأثير داشته و هم جنين داراى اثراتى بر روى اين كود كان نيز باشد (بيلى و همكاران؟ . $(r \cdot 1 r$ آموزش شناخت درمانى مبتنى بر ذهن آكاهى عبارت است از تجربه كامل افكار و احساسات آدمى تنها به عنوان يديدههاى ذهنى گذرا كه برخلاف روشهاى شناختى و رفتارى بدون هيج گونه نياز به تحليل محتوا يذيرفته مىشوند. اين درمان مبتنى بر تنظيم توجه، ايجاد

\footnotetext{
1. Chronis,chako,Fabiano,wymbs,pelham

2 - Davis \& Carter

3- Kuhn

${ }^{4}$ - Bailey et al

6- Teasdale, segal \& williams

7. Williams \& penmen

8 - Cachia
} 
مطلوبى بر نظام خانو اده مى كذارد. هم جنين از آن جايى كه تأثير ذهن آكَاهى و شناخت درمانى مبتنى بر ذهن آكاهى بر كاهش استرس و افزايش بهزيستى روانشناختى كروههاى مختلف بالينى و غير بالينى تائيد شده است و واستر

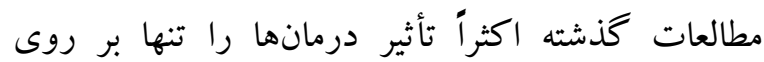
مادران كود كان اوتيسم بررسى كردهاند و علائم كود كان كمتر بررسى شده است، هدف از ئزوهش حاضر بررسى تأثير آموزش شناخت درمانى مبتنى بر ذهن آكاهى بر بره

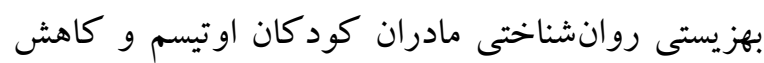
علائم اين كود كان است.

\section{روش}

طرح يزوهشى مطالعه حاضر از نوع شبه آزمايشى با طرح

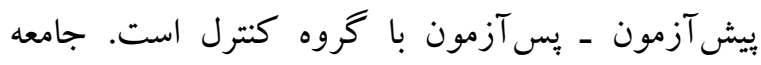
يثزوهشى حاضر شامل كليه مادران داراى كودك اوتيسم است كه به مراكز اوتيسم شهر اصفهان مراجعه كرده و

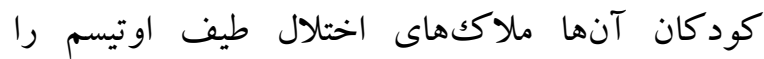
دريافت كرده بودند. نمونه ئزوهش شامل ·r نفر از مادران كود كان اوتيسم مىباشند كه به روش نمونه گيرى در دسترس انتخاب كرديدند. بدينصورت كه با مراجعه به دو مركز اوتيسم اين گروه از مادران انتخاب و به به بـ صورت تصادفى در دو گروه كنترل و آزمايش قرار

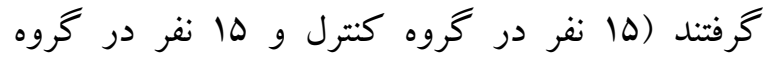
آزمايش). هم جنين لازم به ذكر است كه گروه ها از نظر ويزگى هاى جمعيت شناختى از قبيل سن، وضعيت اجتماعى - اقتصادى، سطح تحصيلات و ... هم تا شدند. در اين بثزوهش ملاكك هاى ورود شامل: ا. مادران داراى كودك اوتيسم، r. تمايل براى شركت در اين برنامه

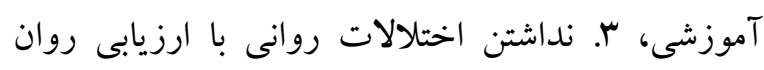

روان شناختى مادران را افزايش و استرس را در آن ها

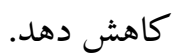
دى بروين و همكاران' (Y. F) و سينگ و و همكاران (Y..V) مداخلات ذهن آكاهى براى والدين مى تواند منجر به كاهش يافتن استرس و اضطراب و افزايش تعاملات والدين با كود كك در والدين كود كان اوتيسم شود. ليلى و

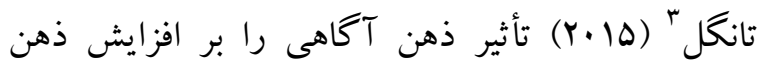
آكاهى و كاهش استرس در والدين كود كان اوتيسم مورد بررسى قرار داده و به اين نتيجه دست يافتند كه اين درمان مى تواند در اين گروه از والدين مؤثر باشد.

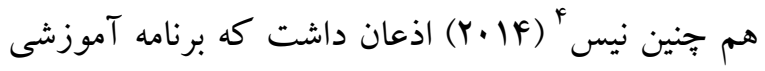
كاهش استرس مبتنى بر ذهن آكاهى مى تواند بر استرس و سلامت روانى والدين كودكان با تأخير رشدى تأثير داشته و به دنبال آن منجر به كاهش مشكلات رفتارى در اين كودكان شود. در حقيقت تحقيقات نشان مىدهند مداخلات مىتواند والدين كود كان اوتيسم را قدرتمند كرده و سلامت روانى و بهزيستى آنها را افزايش دهد كه اين موارد كمكك مى كند تا كود كانشان روند بهترى را در درمان طى نمايند (كاجيا و همكاران، 19. (Y). با توجه به مطالب فوق در زمينه مشكلات مادران كود كان اوتيسم و تأثير اين مشكلات بر روند مداخلات در اين

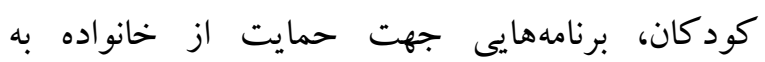
خصوص بهبود سلامت روان و بهزيستى روان شناختى مادران با توجه به اينكه بيشترين ارتباط را با كودك دارد بسيار كار ساز بوده و به خانواده در يذيرش مسئله و انطباق درست با شرايط كودكى كمكك كرده و تأثير

\footnotetext{
1- De Bruin et al

2 - Singh et al

3 - Lilly \& Tungol

${ }^{4}$ - Neece
} 
گُرديد. بهزيستى روانشناختى ريف يكك برسش نامه جند

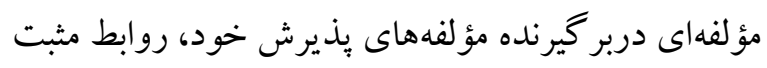
با ديخران، خودمختارى، تسلط بر محيط، زندگى هدفمند و رشد فرد است. مجموع نمرات اين 9 عامل به عنوان نمره كلى بهزيستى روان شناختى محاسبه مى شود.

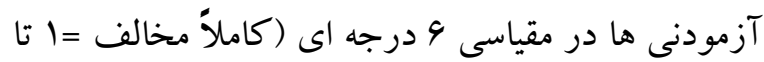

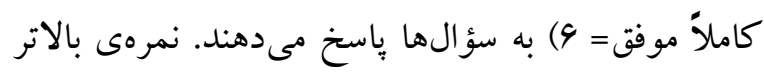
نشان دهندهى بهزيستى روان شناختى بهتر است. ريف

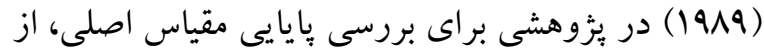
آلفاى كرونباخ بهره گرفت. آلفاى به دست آمده براى

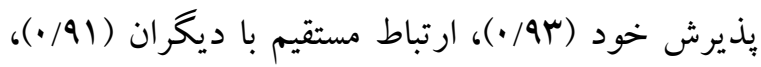

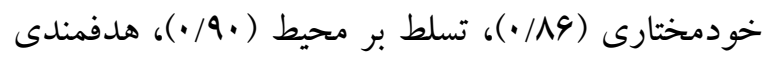

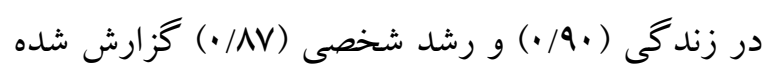
است كه بر اين اساس براى اهداف بزوهشى و بالينى ابزار

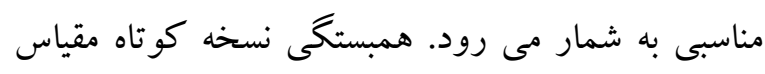
بهزيستى روان شناختى ريف با مقياس اصلى از V/. تا

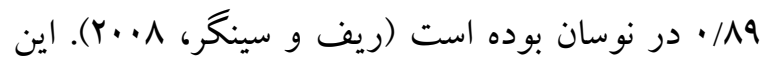
مقياس در ايران توسط سفيدى و فرزاد (IMAN) در يُخوهشى با عنوان روا سازى آزمون بهزيستى روان شناختى ريف در دانشجويان دانشگاه قزوين هنجاريابى

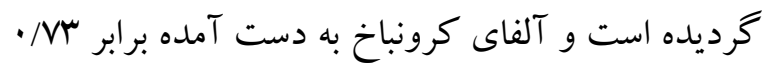
كزارش شده است. در اين بثوهش از فرم هF سؤالى مقياس استفاده شده است. مقياس رتبهبندى مشكلات رفتارى كود كان اوتيسه كيليام (GARS) و هر كدام F|f كويه دارد، نخستين خرده مقياس، رفتارهاى كليشهاى و شامل بندهاى ا تا Fا است. اين خرده آزمون، رفتارهاى كليشهاى، اختلالات حر كتى و رفتارهاى عجيب وغريب را توصيف مى كند. خرده مقياس دوم كه برقرارى ارتباطات است، بندهاى ها تا ب ر را شامل
شناس بالينى و ملاكك هاى خروج: 1. داشتن اختلالات روانى ז. شركت همزمان در دوره هاى درمانى ديخر و ؟ّ. غيبت بيش از دو جلسه. هم جنين ملاحظات اخلاقى كه در اين ئزوهش مورد توجه قرار كرفت عبارتاند از: ا. ناشناس بودن نمونهها r. تمايل آنها براى شركت در بُزوهش و س. استفاده از

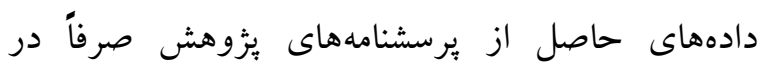
راستاى اهداف و فرضيههاى يثزوهش. شيوه اجراى يزوهش به اين صورت بود كه بس از مراجعه به دو مركز اوتيسم شهر اصفهان ·r نفر از مادران به شيوه در دسترس انتخاب شدند و به صورت تصادفى در ץ گروه ها نفرى گمارده شدند (يكك گروه آزمايش ويك گروه كنترل). برسشنامه بهزيستى روانشناختى ريف فرم هF سؤالى و مقياس كيليام به عنوان بيش آزمون در اختيار مادران قرار گرفت. در مرحله بعدى بر روى كروه آزمايش شناخت درمانى مبتنى بر ذهن آكاهى در طى ده جلسه (هر جلسه يكك ساعت و نيم) اجرا كرديد. اين جلسات در يكى از مراكز مشاوره و روان شناسى اصفهان انجام شد. در جلسه آخر مجدداً يرسشنامه بهزيستى روانشناختى ريف و مقياس گيليام اجرا شد. در بايان هر جلسه فرم يادداشت تكاليف خانگى در اختيار شر كت كنند گان قرار مى كرفت.

ابزار مقياس بهزيستى روانشناختى ريف (PWBS):' مقياس بهزيستى روانشناختى در سال 1919 توسط كارول ريف در دانشگاه ويسكانسين ساخته شده است. فرم اصلى آن

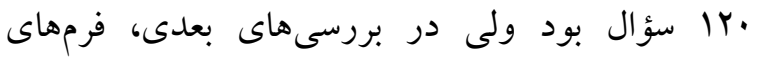
كوتاهتر NF سؤالى، DF سؤالى و M سؤالى نيز بيشنهاد

\footnotetext{
1- Psychological Well-being Scale, Ryff
} 
ساير سيستمهاى ارزيابى و غربالكرى اوتيسم تائيد شده است. احمدى، صفرى، همتيان و خليلى (.9 وسا) ضريب آلفاى كرونباخ را در رفتاركليشه اى VF+•• برقرارى ارتباط צو/ • و تعاملات اجتماعى سل/ • به دست آوردند. همجينين در يثوهش آن ها ميزان اين ضريب براى كل

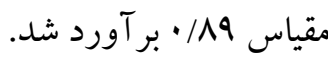
يروتكل درمانى بر طبق كابات زين و همكاران (1994) انجام شد. اين بروتكل در تحقيقات مختلف مورد استفاده قرار گرفته و نتايج حاكى از اثربخشى اين روش درمانى بر افسردگى، اضطراب و بهزيستى روان شناختى است

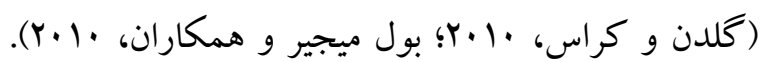
در زير خلاصهاى از جلسات شناخت درمانى مبتنى بر ذهن آكاهى آورده شده است.
مىشود. اين آيتمها رفتارهاى كلامى و غير كلامى را توصيف مى كند كه نشانهايى از اوتيسم هستند. تعاملات اجتماعى سومين خرده مقياس است كه شامل بندهاى تا F F است. خرده مقياسهاى رفتارهاى كليشهاى، ارتباط و تعامل اجتماعى داراى بِاسخ هيج كاه، به ندرت، كاهي اوقات و اغلب (بسيارزياد) هستند كه به ترتيب نمره

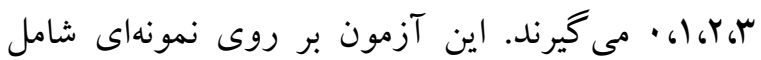

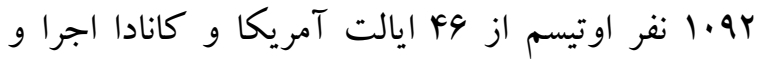
استاندارد شده و قابليت پايايى آن از طريق ضريب آلفاى

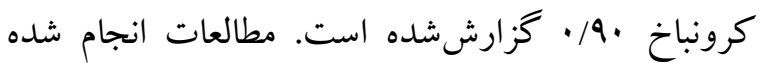

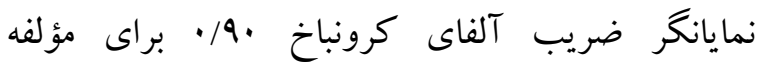

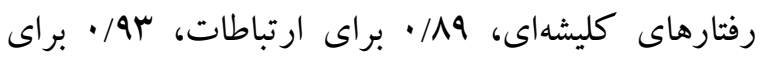
تعامل اجتماعى است. اعتبار آن نيز از طريق مقايسه با

جدول 1 سرفصل محتواى آموزش شناخت درمانى مبتنى بر ذهن آكاهى

\begin{tabular}{|c|c|}
\hline 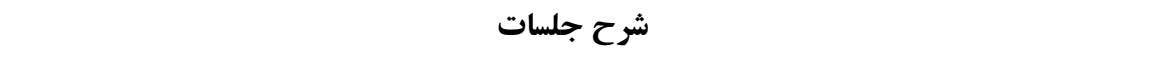 & جلسه \\
\hline بيان اهداف آموزش جلسات، معرفى اعضا و محرمانه بودن، معرفى روش شناخت درمانى مبتنى بر ذهن آكاهى، & 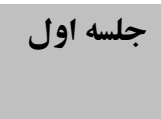 \\
\hline هدايت خود كار، تعريف حضور ذهن، ماندن در زمان حال و بدون قضاوت & 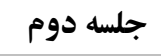 \\
\hline مقابله با موانع، آموزش فنى وارسى بدن، كنترل ذهن سركردان با تمرين وارسى & جلسه سوم \\
\hline نشسته رضور ذهن بر روى تنفس، تمرين تنفس باحالت حضور ذهن و به دنبال آن انجام تأمل در وضعيت نشسته، مراقبه & جلسه جهارم \\
\hline ماندن درزمان حال، فضاى تنفس سه دقيقه اى، گسترش دادن توجه با روش مراقبه شنيدن & جلسه ينجم \\
\hline ايجاد رابطه اى متفاوت با تجربه، جگگ نخى ايجاد و استفاده از بذيرش & جلسه ششم \\
\hline مرورى بر بحث افكار حقايق نيستند و روشهايى كه با استفاده از آنها مى توان افكار را به نحو متفاوتى ديد & جلسه هفتم \\
\hline مرورى بر مراقبت از خود، ارتباط فعاليت و خلق، يكيارجخى فعالسازى رفتارى در آموزش برنامهر يزى فعاليتها & جلسه هشتم \\
\hline استفاده از آموختهها براى داشتن رضايت از خود، مرورى به جلسات كذشته و خلاصه بندى & جلسه نهم \\
\hline توزيع فرم نظرخواهى بين شر كت كند كان و اجراى بس آزمون & جلسه دهم \\
\hline
\end{tabular}

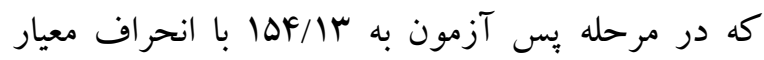

يافتهها

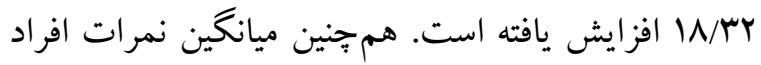
شاخصهاى توصيفى نمرات گروه آزمايش در بهزيستى كروه كنترل در بيش آزمون بr/ها با انحراف معيار روان شناختى به اين ترتيب بود كه ميانكين نمرات در لور

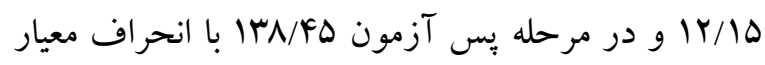

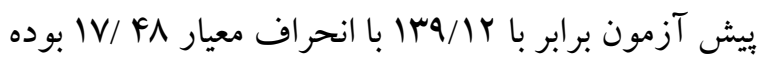


در اين يزوهش جهت تعيين اثر بخشى شناخت درمانى مبتنى بر ذهن آكاهى بر بهزيستى روان شناختى مادران

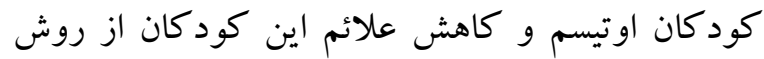
تحليل كوواريانس استفاده شد. لازم به ذكر است كه از مفروضههاى آزمون تحليل كوواريانس، شرط نرمال بودن داده ها و همسانى واريانس هاى گروهها است. نتايج آزمونهاى كولمو گروف- اسميرنف و لوين نشان دادند شرط نرمال بودن و همسانى واريانسها برقرار است. هم جنين در اين بثزوهش نمرات بيش آزمون كنترل شده

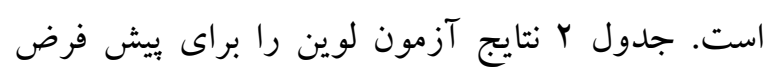
همسانى واريانس ها نشان مى دهد. هץ/·r است. ميانگين و انحراف معيار گروه آزمايش در مرحله بيش آزمون، در مقياس مشكلات رفتارى گيليام به

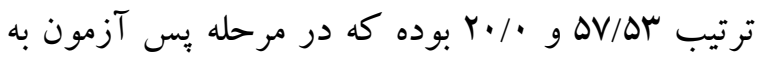

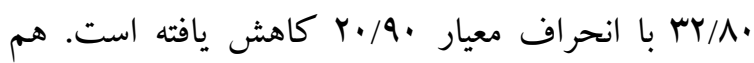
جنين ميانگين نمرات افراد كروه كنترل در بيش آزمون سه/DV

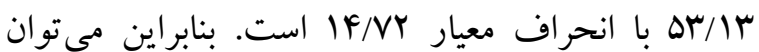
نتيجه گرفت كه ميانگين گروه آزمايش در مرحله بس آزمون در بهزيستى روانشناختى افزايش و در مقياس گيليام كاهش يافته است.

جدول ץ نتايج آزمون لوين براى بررسى ييش فرض تساوى واريانس ها

\begin{tabular}{|c|c|c|c|c|}
\hline سطح معنادارى & درجه آزادى & درجه آزادى & آناليز واريانس & متغير هاى وابسته \\
\hline$\cdot / M r$ & rA & 1 & $r / F V$ & روانشناختى \\
\hline .1 .9 & ru & 1 & $r / 91$ & علائم اوتيسم \\
\hline
\end{tabular}

شناختى و علائم اوتيسم را نشان مى دهد. لازم به ذكر

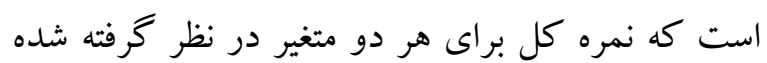

همانطور كه در جدول r ملاحظه مىشود شرط همسانى واريانسها براى هر دو متغير بهزيستى روان شناختى و علائم اوتيسم برقرار است. جدول r نتايج تحليل كواريانس در مورد تفاوت دوتر كروه كنترل و آزمايش در متغيرهاى بهزيستى روان

جدول ب خلاصه نتايج آزمون تحليل كواريانس تفاوت دو كروه در متغيرهاى مورد مطالعه

\begin{tabular}{|c|c|c|c|c|c|c|c|}
\hline توان & ميزان تأثير & معنادارى سطح & واريانس & مجذورات مياتكين & آزادى درجه & مجذوروات & منبع \\
\hline \multicolumn{8}{|c|}{ بهزيستى روانشناختى } \\
\hline$\cdot / A \cdot$ & $\cdot / 44$ & $\%$ & $1 / \pi \Delta$ & $999 \mathrm{~V} / 9 \mathrm{~A}$ & 1 & $994 \mathrm{~V} / 91$ & كروه \\
\hline.$/ 9 F$ & r r l r &.$/ . .1$ & $\mid r / \wedge \Delta$ & IV৭৭४/৭. & 1 & IV৭৭১/9. & يشي آزمون \\
\hline
\end{tabular}

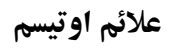




\begin{tabular}{|c|c|c|c|c|c|c|c|}
\hline$\cdot / 9 \mathrm{~V}$ & $\cdot / \mu \Lambda$ & $\cdot / \cdot 1$ & 191.9 & $r q 19 / \Delta r$ & 1 & $r q 19 / \Delta r$ & كروه \\
\hline$\cdot / 9 F$ & • &.$/ \cdots 1$ & $19 / 49$ & raVD/FF & 1 & raVD/FF & يِي آزمون \\
\hline
\end{tabular}

$\mathrm{p} \leq / . .1$

آموزش ذهن آكاهى بر روى مادران كودكان اوتيسم

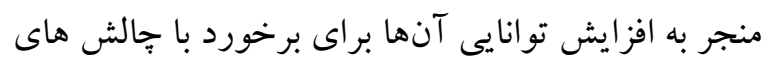
رفتارى در اين كودكان مى شود، بر كاهش استرس اين

مادران داراى تأثير است (سينگك و همكاران، Y. Y F). دو مطالعه طولى تأثير غير مستقيم آموزش ذهن آكاهى والدين را بر كاهش يرخاشخرى و افزايش رفتارهاى مثبت در كودكان اوتيسم نشان داده اند (كاجيا و همكاران، (Y) (Y). اين يافته، مرتبط با يُوهش حاضر است. به اين ترتيب كه برنامه هاى ذهن آكاهى طراحى

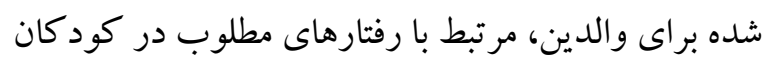
اوتيسم است. در يكى از اين دو مطالعه طولى نتايج نشان دادند كه برنامه ذهن آكاهى نه تنها استرس را در والدين كودكان اوتيسم كاهش داد بلكه منجر به تغييراتى در رفتارهاى كودكك، بهبود تئورى ذهن، انسجام مركزى و كاركردهاى اجرايى در كودكان اوتيسم شد (كاجيا و

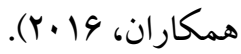
در توجيه اين يافته كه جرا آموزش شناخت درمانى مبتنى بر ذهن آكَاهى بر بهزيستى روانشناختى مادران تأثير

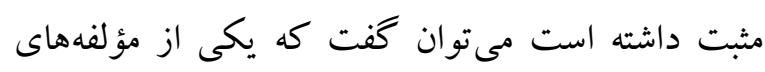
مهم در اين روش توجه است و ذهن آكاهى به واسطه توجه كردن به صورت عمد و كامل به اينجا و اكنون باعث مى شود كه افكار مزاحم به حاشيه آكاهى برده

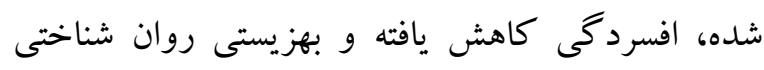

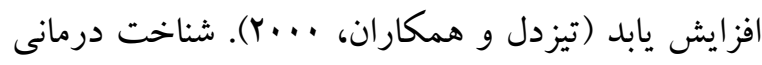
مبتنى بر ذهن آكاهى، مراقبه براى كمكك به افراد را در برمى گيرد تا از تجاربشان در لحظه حال آكاهتر شوند و متوجه زمانى كه خلق شان شروع به بايين آمدن مى كند،
با توجه به جدول ب دورهى شناخت درمانى مبتنى بر ذهن

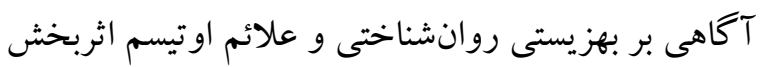
بوده است. ميزان تأثير به ترتيب در متغيرهاى بهزيستى

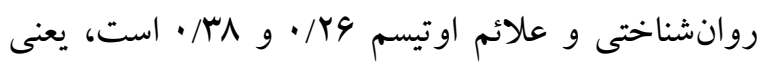

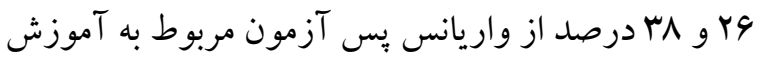
شناخت درمانى مبتنى بر ذهن آكاهى است. همرِين توان آمارى در اين متغير ها ·مو VV9 درصد است.

اين يثوهش با هدف بررسى اثر بخشى آموزش شناخت درمانى مبتنى بر ذهن آكاهى بر بهزيستى روان شناختى مادران كود كان مبتلا به اوتيسم و كاهش علائم اين كود كان انجام گرفت. يافتهاى يثزوهش نشان داد كه بين دو گروه كنترل و آزمايش در متغيرهاى بهزيستى روانشناختى و علائم اوتيسم بعد از آموزش شناخت درمانى مبتنى بر ذهن آكًاهى تفاوت معنادارى وجود دارد. نتايج اين وئوهش با بثزوهش هاى كاجيا و همكاران (Y.|9)

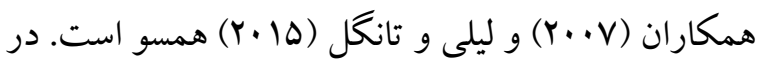
يثزوهش هاى زيادى اثربخشى ذهن آكاهى بر افزايش ذهن آكاهى و كاهش استرس در والدين كود كان اوتيسم

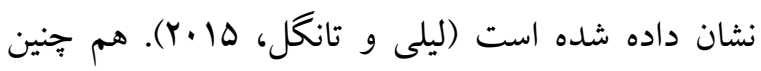
مداخلات ذهن آكاهى مى تواند منجر به كاهش اضطراب و افزايش تعاملات والد - كودكك در والدين كودكان

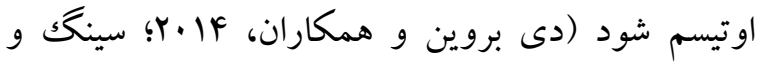

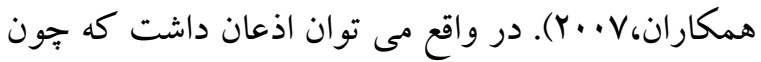


كه واكنش اوليه بيشتر مادران به هنگام تشخيص اوتيسم در كودكانشان به صورت انكار، احساس ناميدى و و كاهش اعتماد به نفس است. والدين كودكى، مشكلاتى در مديريت رفتارهاى مشكل آفرين، آموزش مهارتهاى ارتباطى به كودك،، آموزش مهارت هاى زندكى با حفظ

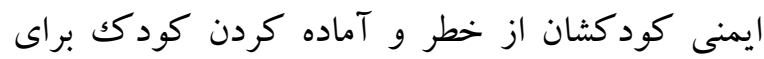
زندكى بزرگكسالى دارند. اين عوامل به فرزند يُوورى إنى ناكارآمد منجر شده و همجنين باعث ترس، اضطراب، نخر انى، غم و اندوه مادران، عدم ارتباط مؤثر بين والدين و كودك مبتلا به اوتيسم مى گردد (شجاعى، ذهن آكاهى از جمله روشهايى است كه بر آكاهى فكرى تأكيد مى كند. وجود ذهن آكاهى باعث مىشود كه والدين در تعامل با فرزندانشان به صورت هدفمند عمل كنند. در حقيقت ذهن آكاهى والدين كامى است كه باعث بهبود عملكرد سازشى والدين در آكاهى و توجه متمركز در تعامل با فرزندان، يذيرش نامشروط و بدون قضاوت رفتارهاى فرزندان، توانايى نظم دادن به واكنشهاى خود در قبال آنها، تقريب لحظهبهلحظه رفتارهاى مثبت كودكان، افزايش رفتارهاى مثبت و كاهش رفتارهاى منفى آن ها و در نهايت كاهش مشكلات رفتارى كود كان مىشود. به طورى كه مىتوان كفت هنگامى كه مادر مؤلفه هاى سلامت روان را داشته باشد، مى تواند محيطى غنى و سالم براى كودكك داراى

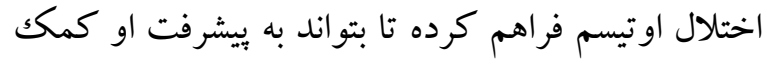
كند؛ بنابراين توجه به عوامل مؤثر در افزايش سلامت روان براى اين مادران مىتواند تأثير بسزايى در كاهش رفتار مخرب اين كودكان داشته باشد (حسين زاده، كاكاوند و احمدى، لهوب(1).
باشند تا از اين طريق ارتباط خلق منفى و افكار منفى فراخوانده شده توسط آن شكسته شود و ياد بحيرند در زمان پايين آمدن خلق جطور از خود مراقبت كنند (كويكن، كرين و ويليامز، Yإب). اين روش منجر به كسترش افكار جديد، كاهش هيجانات ناخوشايند، كاهش نشخوار فكرى و پِاسخهاى اضطراب آينده و افزايش بهتر كيفيت زندكى مى شود. ذهن آكاهى نقش مؤثرى در افزايش بهزيستى روانشناختى و كاهش

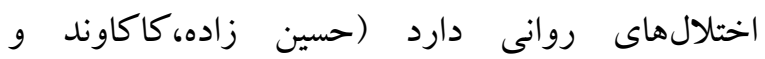

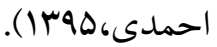
همجنين شركت منظم در جلسات و درگيرشدن با با تجارب ذهنى به شكلى صحيح موجب داشتن هدف و انكيزه در زندكى شخص شده است. جرا كه در ذهن آكاهى افراد ياد مى گيرند به زندگى و اطرافشان توجه كرده، استانداردهاى خود را افزايش داده و به اين باور برسند كه با برنامه ريزى و شناخت موانع و تمر كز بر زمان

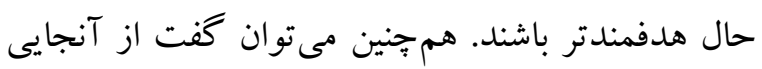
كه هيجانات نقش مهمى در زندگى ايفا مى كنند و ذهن آكاهى به عنوان يك روش درمانى در تعديل هيجانات، با بهزيستى روانشناختى فرد در ارتباط است، باعث ارزيابى مثبت فرد از موقعيتهاى زندگى شده و افزايش فعاليت و ياسخ مثبت به موقعيتها و در نهايت افزايش بهزيستى روان شناختى مادران را به دنبال دارد. در تبيين اين يافته نيز كه جرا آموزش شناخت درمانى مبتنى بر ذهن آكاهى باعث كاهش علائم اوتيسم در كود كان شده است، مىتوان كفت كه والدين كود كان مبتلا به اوتيسم در قياس با والدين كود كان عادى استرس بالاترى را تجربه مى كنند. در يخوهشى كه جيمه،

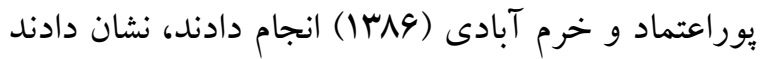

\section{نتيجه كيرى}


در يايان از تمامى مادران كودكان اوتيسم كه با وجود مشكلات فراوان محققان را در انجام بيزوهش يارى

$$
\text { كردند، تشكر و قدرانى مى گردد. }
$$

\section{References}

Aghababaei S, Abedi A, Yarmohammadian A \& Zamani N. (2015). Meta-Analysis of the effectiveness of applied behavioral analysis intervention on language skills in autism children. Joumal of Clinical Psychology, 2, 7, 77-86. (InPersian)

Ahmadi Z, Safari S, Hematian T \& Khalili Z (2012). Gilliam autism rating scale Manual. Isfahan: Jahad daneshgahi publication (In Persian).

Ahmadvand Z, Heidari nasab L \& Shairi M. (2012). Prediction of Psychological Well - Being Based on the Comonents of Mindfulness. Health Psychology, 1, 2, 60-70 (In Persian).

American Psychiatric Association. (2013). Diagnostic and statistical manual of mental disorders (5th Ed.). Washington, DC: Author.

Bailey DB, Raspa M \& Fox L. C. (2012). What is the future of family outcomes and family-centered services? Topics in Early Childhood Special Education, 31(4), 216-223.

Baio J. (2012). Prevalence of autism spectrum disorders -Autism and developmental disabilities monitoring network, 14 sites, United States, Surveillance summaries, Morbidity and Mortality Weekly Report. Center for disease control and prevention.

Baker BL, Blacher J, Cmic KA \& Edelbrock C. (2002). Behavior problems and parenting stress in families of three-year-old children with and without developmental delays. American Journal on Mental Retardation, 107(6), 433 444.

Blacher J \& McIntyre LL. (2006). Syndrome specificity and behavioral disorders in young adults with intellectual disability: cultural differences in family impact. Journal of Intellectual Disability Research, 50(3), 184-198.
در كل نتايج اين يزوهش نشان داد كه مداخله شناخت درمانى مبتنى بر ذهن آكاهى تأثير مثبتى بر بهزيستى روانشناختى مادران كود كان اوتيسم دارد و اين تأثير مى تواند رفتارهاى كود كان اوتيسم آنها را نيز تحت تأثير قرار دهد. در بايان مىتوان نتيجه كرفت كه انجام اين تمرينات باعث توجه به خود در لحظه، زير نظر داشتن افكار و احساسات در برخورد با موقعيتها، افزايش سلامت روانى مادران و برخورد مناسب با علائم اين كودكان شده است. درحالى كه اضطراب و افسردگى مادر بر مشكلات كودكان اوتيسم تاثير دارد. در نتيجه توجه به عوامل مؤثر در سلامت روان مادران و ايجاد جلسات آموزشى در جهت افزايش بهزيستى روان شناختى آنها مىتواند تأثير بسزايى در كاهش مشكلات رفتارى و كاهش علائم اين كود كان داشته باشد. در واقع روانشناسان، روان يزشكان و ساير متخصصان كودكان اوتيسم به خصوص مربيانى كه در حوزه آموزش به

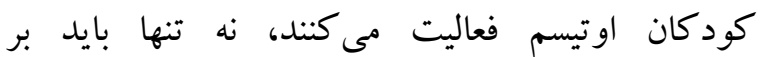
راهكارهاى متمركز بر كودك داراى اختلال طيف اوتيسم توجه كنند، بلكه به شرايط بهداشت روانى والدين و محيط خانواده، منابع موجود در جامعه و ساير عوامل مربوطه به افت زندگى كودكك نيز توجه داشته و در آموزش كودكك اين عوامل را لحاظ نمايند. يكى از محدوديت هاى يثزوهش حاضر نداشتن مرحله بيßيرى بود تا بتوانيم تأثير اين درمان را بر روى والدين و كود كان اوتيسم در طول زمان بررسى نماييم. بيشنهاد مى شود در مطالعات مشابه با بثزوهش حاضر مرحله بيخيرى هم مورد توجه قرار گيرد. سياسگزارى 
Bohlmeijer E, Prenger R, Taal E \& Cuijpers P. (2010). "The effects of mindfulness-based stress reduction therapy on mental health of adults with a chronic medical disease: A metaanalysis". Journal of Psychosomatic Research, 36 (68): 539-544.

Cachia RL, Anderson A \& Moore DW. (2016). Mindfulness, stress and well-being in parents of children with autism spectrum disorder: a systematic review. Journal of Child and Family Studies, 25(1), 1-14.

Chimeh N, Pouretemad H \& Khoram Abadi R. (2008). Need Assessment of Mothers with Autistic Children. Journal of Family Research, 3, 3, 697-707 (In Persian).

Davis NO \& Carter AS. (2008). Parenting stress in mothers and fathers of toddlers with autism spectrum disorders: associations with child characteristics. Journal of Autism and Developmental Disorders, 38(7), 1278-1291.

De Bruin EI, Blom R, Smit FM, Steensel V \& Bögels SM. (2014). MYmind: mindfulness training for youngsters with autism spectrum disorders and their parents. Autism, 19,906-911.

Dumas J. (2005). Mindfiulne based parent training, strategies to lessen the gri of automaticity in families with disnuptive children. Journal of Clinical Child and AdolescentPsychology, 34, 779-791.

Eisenhower AS, Baker BL \& Blacher J. (2005). Preschool children with intellectual disability: syndrome specificity, behavior problems, and matemal well-being. Joumal of Intellectual Disability Research, 49(9), 657-671.

Falk NH, Norris K \& Quinn MG. (2014). The factors predicting stress, anxiety and depression in the parents of children with autism. Journal of Autism and Developmental Disorders, 44(12), 3185-3203.

Frantz R, Hansen SG \& Machalice W. (2017). Interventions to promote well-being in parents of children with autism: a systematic review. Review Journal of Autism and Developmental Disorder, 5, 18, 1-21.

Giallo R, Wood CE, Jellett R \& Porter R. (2013). Fatigue, wellbeing and parental self-efficacy in mothers of children with an autism spectrum disorder. Autism, 17(4), 465-480.

Goldin PR \& Gross JJ. (2010). 'Effects of mindfulness based stress reduction (MBSR) on emotion regulation in social anxiety disorder'. Emotion. 25(10): 83-91.

Hosseinzade Z, kakavand A \& Ahmadi A. (2016). The Mediating Role of Mother Mindfulness and Family Resilience in the Relationship between Behavioral Problems in Children with Autism Spectrum Disorders and Mother Psychological Well-being. Psychology of Exceptional Individuals Journal, 23, 152-164 (In Persian).

Kabat Zinn I. (1990). Full Catastrophic living: using the wisdom of your body and mind to face stress, pain, and illness. New York: pleacorte.

Kuhn JC \& Carter AS. (2006). Matemal self-efficacy and associated parenting cognitions among mothers of children with autism. American Joumal of Orthopsychiatry, 76(4), 564-575.

Kuyken W, Crane R \& Williams M. (2012). Mindfulness-based Cognitive therapy (MBCT) Implementation Resources. Mindfulness centers at Exeter Bangor and oxford Universities.

Lilly J \& Tungol JR. (2015). Effectiveness of mindfulness based psycho-educational program on parental stress of selected mothers of children with autism. Indian Joumal of Positive Psychology, 6(1), 52-56.

Neece CL. (2014). Mindfulness-based stress reduction for parents of young children with developmental delays: applications for parental mental health and child behavior. Joumal of Applied Research in Intellectual Disability, 27, 174-186.

Parvaneh E, Momeni KH, Parvaneh E \& Karimi, P. (2015). Predicted psychological well-being according to spiritual intelligence and hardiness of student's female. Islam \& Health Joumal, 1, 4, 14-20 (In Persian).

Sefidi F \& Farzad V. (2009). Validated measure of Ryff psychological well-being among students of Qazvin University of Medical Sciences. The 
Journal of Qazvin University of Medical Sciences, 16, 1, 65-71 (In Persian).

Shojaei S. (2015). Challenges Facing Families with Children with Autism Spectrum Disorders. Quarterly Journal of Child Psychological Development, 2, 1, 71-82 (In Persian).

Singh NN, Lancioni GE, Winton AS, Singh J, Curtis WJ, Wahler RG \& McAleavey KM. (2007). Mindful parenting decreases aggression and increases social behavior in children with developmental disabilities. Behavior Modification, 31, 749-771.

Teasdale JD, Williams JM, Segal ZV, Ridgeway VA, Soulsby JM \& Lau MA. (2000). Prevention of relapse recurrence in major Depression by mindfulness based cognitive therapy Journal of consulting and clinical psychology, 68, 615623.

Teasdale YD, segal ZR \& williams MG. (1995). How does cognitive therapy prevent depressive relapse and why should intentional control mindfulness training help? Behavior Reserch and Therapy, 33, 25-39.

Tomanik S, Haris GE \& Hawkins J. (2004). The relationship between behaviors exhibited by children with autism and maternal stress. Journal of Intellectual and Developmental Disability, 29(1), 16-26.

Williams M \& Penmen D. (2012). Mindfulness: A practical Guide to Finding peace in frantic word piatkus. Co.uk. 